\title{
Analisis Pengelolaan Keuangan dalam Peningkatan Pembangunan di Desa Angkasa Pura
}

\author{
Doni Mhd. Hasrul \\ Fakultas Ilmu Sosial, Universitas Negeri Padang, Padang \\ *Corresponding author, e-mail: Donimhdhasrul1998@gmail.com
}

\begin{abstract}
This study aims to determine village financial management in increasing development in Angkasa Pura Village, Sitinjau Laut District, Kerinci Regency. This research is motivated by several problems such as lack of human resources, people who do not know about the village financial management system, lack of public understanding of village development programs, lack of cooperation and coordination on village development issues whose development goals are to promote and prosper rural communities. The approach used in this study is a qualitative approach. The informants in this study amounted to 7 people. Techniques and data collection in this study in the form of interviews, observation and documentation. The Unit of Analysis is an individual, social group or institution from the Village Apparatus in Angkasa Pura Village, Sireview Laut District. The results showed that village financial management activities were not optimal, especially in the administration and reporting stages, thus hampering the planned activities.
\end{abstract}

Keywords: Financial Management, Village Development

Received February 21, $2021 \quad$ Revised November 25, $2021 \quad$ Published December 7, 2021 author.

\section{Pendahuluan}

Pemerintah Indonesia sampai saat ini terus melakukan peningkatan pelaksanaan pembangunan nasional agar pembangunan daerah serta pembangunan wilayah desa dan wilayah kota semakin seimbang. Namun pembangunan nasional pada pelaksanaannya masih dihadapkan dengan masalah pokok pembangunan salah satunya seperti ketimpangan pembangunan antara daerah desa dan daerah kota di wilayah Indonesia.

Dengan disahkannya UU Nomor 6 Tahun 2014 tentang Desa serta turunannya yaitu Peraturan Pemerintah Nomor 43 Tahun 2014 tentang Desa, Peraturan Pemerintah Nomor 60 Tahun 2014 tentang Dana Desa yang bersumber dari APBN, serta beberapa aturan teknis dari Kementrian Dalam Negeri diantaranya yaitu Permendagri Nomor 113 Tahun 2014 tentang Pengelolaan Keuangan Desa, di mana desa diberikan kesempatan untuk mengurus dan mengelola pemerintahan daerah masing-masing serta pelaksanaan pembangunan untuk mensejahterakan dan meningkatkan kualitas hidup masyarakat Indonesia di desa. Pemerintah desa sendiri diharapkan untuk lebih mandiri dalam mengelola pemerintahan dan berbagai sumber daya alam yang dimiliki, termasuk pengelolaan keuangan dan kekayaan milik desa.

Dalam menyusun dan mengelola anggaran desa, kepala desa dibantu oleh badan yang bertugas menetapkan Anggaran Pendapatan dan Belanja Desa (APBDesa) disetiap tahun sesuai dengan peraturan. Untuk mewujudkan cita-cita pembangunan di Pemerintahan Desa, maka pelaksanaan proses pembangunan khususnya masalah keuangan harus dilaksanakan dan dikelola oleh aparat desa bersama sama dengan masyarakat desa sehingga dapat dihindari kondisi di mana dapat mengakibatkan tersendatnya pembangunan maupun penyalahgunaan wewenang yang menghambat tercapainya pembangunan itu sendiri.

Pembangunan yang dilaksanakan di desa merupakan salah satu realisasi pembangunan nasional. dalam menunjang pembangunan di desa dibutuhkan partisipasi seluruh lapisan masyarakat. Dalam rangka merealisasikan tujuan pembangunan maka segenap maupun 
seluruh potensi alam harus digali, dikembangkan, dan dimanfaatkan sebaik-baiknya, demikian pula halnya sumber daya manusia harus lebih ditingkatkan sehingga dapat mengembangkan potensi alam secara maksimal agar tujuan pembangunan dapat tercapai dengan maksimal.

Desa Angkasa Pura Kecamatan Sitinjau Laut Kabupaten Kerinci telah menerima alokasi dana desa dari pemerintah daerah sehingga setiap aparat di Desa Angkasa Pura dituntut mampu mengelola alokasi dana desa ataupun keuangan desa sesuai dengan pembangunan desa berbasis pemberdayaan. Desa Angkasa Pura selalu berusaha untuk berkembang melalui pemamfaatan sumber daya yang tersedia baik sumber daya alam maupun sumber daya manusia.

Adapun yang menjadi permasalahan di Desa Angkasa Pura yaitu:

1. Kurangnya Sumber Daya Manusia, yang mau turut serta dalam pelaksanaan pengelolaan keuangan desa. Hanya ada beberapa anggota aparat desa yang bersedia membantu pelaksanaan pengelolaan keuangan desa. Fenomena ini dapat sedikit mencerminkan keseriusan aparat Desa Angkasa Pura dalam menjalankan profesinya sebagai aparat desa yang dampaknya pada profesionalitas aparat desa tersebut.

2. Masyarakat di Desa Angkasa Pura belum sepenuhnya mengetahui dana yang dikelola dan sistem pengelolaan keuangan desa.

3. Kurangnya pemahaman masyarakat terhadap evaluasi program pembangunan desa, karena tidak ada sosialisasi terhadap masyarakat desa.

4. Kurangnya kerja sama atau koordinasi dengan berbagai pihak termasuk masyarakat terutama masalah pembangunan desa. Sehingga masyarakat kurang berpartisipasi dalam pembangunan.

Bambang Triarsono Soemantri (2011) partisipasi masyarakat dalam pembangunan dapat berbentuk partisipasi aktif, artinya masyarakat benar - benar menerima setiap program pembangunan dan ikut terlibat baik dalam perencanaan, pelaksanaan serta pemanfaatan hasil pembangunan, sedangkan partisipasi yang berbantuk pasif artinya masyarakat tidak menolak program pembangunan dan juga tidak terlibat atau berperan serta. Kurangnya sumber informasi serta saran yang dapat membantu kepala desa dan aparat desa dalam mengalokasikan dana sehingga tidak terciptanya keterbukaan antara masyarakat dan pihak pengelola keuangan desa.

Berdasarkan latar belakang di atas, maka yang dapat dirumuskan menjadi pokok permasalahan dalam penulisan ini adalah Bagaimanakah Pengelolaan Keuangan Desa dalam Peningkatan Pembangunan di Desa Angkasa Pura Kecamatan Sitinjau Laut Kabupaten Kerinci?

\section{Tinjauan Kepustakaan}

Desa yang telah memiliki Undang - Undang tersendiri harus dapat dikelola dengan baik, dalam penelitian Wijaya \& Roni (2019) yang meneliti tentang Praktik Pengelolaan Keuangan Desa dan Faktor-Faktor Yang Memengaruhinya, pendekatan yang digunakan adalah secara konseptual dan peraturan perundang - undangan. Dengan kesimpulan dari hasil penelitian yaitu masih terjadinya keterlambatan pengesahan Anggaran Pendapatan dan Belanja Desa (APBDes), serta keterlambatan penyampaian laporan pertanggungjawaban realisasi APBDes, Pemerintah Desa juga masih kurang mensosialisasikan kepada masyarakat mengenai pertanggungjawaban penggunaan keuangan desa yang baik dan benar. Selanjutnya dalam penelitian Bawon et al., (2018), yang meneliti tentang Analisis Prosedur Pelaksanaan Pengelolaan Dana Desa pada Desa Passi 2 Kecamatan Passi Barat. Menggunakan Permendagri No. 113 Tahun 2014 sebagai landasan dalam menganalisis permasalahan.

Dari beberapa penelitian di atas maka dalam penelitian ini perlu digunakan pendekatan secara konseptual dan peraturan terkait yang telah ditetapkan dalam hal ini Undang - Undang No 6. Tahun 2014 tentang Desa dan Permendagri No 113. Tahun 2014 Tentang Pedoman Pengelolaan Keuangan Desa. Desa dibentuk atas prakarsa masyarakat dengan memperhatikan asal-usul desa dan kondisi sosial budaya masyarakat setempat. Pembentukan desa dapat berupa penggabungan beberapa desa, atau bagian desa yang bersandingan, atau pemekaran dari satu 
desa menjadi dua desa atau lebih, atau pembentukan desa di luar desa yang telah ada. Pembentukan desa tidak semata-mata sesuai dengan keinginan perangkat desa yang berwenang mengatur keseluruhan kegiatan di desa, seperti halnya dengan pembentukan atau pendirian organisasi baru, pembentukan desa pun memiliki aturan-aturan yang telah ditetapkan, berikut landasan hukum pembentukan desa adalah Undang-Undang Nomor 6 Tahun 2014 tentang Desa dan diatur lebih lanjut dalam PP No 43 tahun 2014 tentang Peraturan Pelaksanaan Undang-Undang Nomor 6 Tahun 2014.

Pemerintah Desa merupakan wakil dari pemerintah nasional, yang penyelenggaraanya ditujukan kepada desa. Pemerintahan Desa adalah suatu proses di mana usaha-usaha masyarakat desa yang bersangkutan dipadukan dengan usaha-usaha pemerintah untuk memberdayakan dan meningkatkan taraf hidup masyarakat. Soleh \& Rochmansjah (2014) diaturnya desa dengan Undang-Undang tersendiri (Undang-Undang No. 6 Tahun 2014 tentang Desa) yang sebelumnya diatur dalam Undang-Undang Nomor 32 Tahun 2004 tentang Pemerintahan Daerah, memperlihatkan kemajuan politik pemerintah untuk menjadikan desa sebagai basis pembangunan yang sejalan dengan visi misi Undang-Undang, di mana negara melindungi dan memberdayakan desa agar kuat, mandiri dan demokratis sehingga tercipta landasan yang kuat dalam melaksanakan penyelenggaraan pemerintahan, pembangunan dan kemasyarakatan menuju terciptanya masyarakat yang adil makmur dan sejahtera.

Untuk mencapai efektivitas dan efisiensi dalam pengelolaan keuangan desa diperlukan sejumlah asas atau prinsip yang harus dijadikan pedoman yaitu asas kesatuan, asas universalitas, asas tahunan, asas spesialitas, asas akuntabilitas, asas proporsionalitas, asas profesionalitas, asas keterbukaan, asas pemeriksaan keuangan oleh badan pemeriksa keuangan (BPK), asas value for money, asas kejujuran, asas pengendalian, asas ketertiban dan ketaatan terhadap peraturan perundang-undangan, asas bertanggung jawab, asas keadilan, asas kepatutan, dan asas manfaat untuk masyarakat (Soleh \& Rochmansjah, 2014). Berbagai asas atau prinsip pengelolaan keuangan tersebut perlu dijadikan pedoman dalam mengelola keuangan desa, agar dana yang jumlahnya tidak sedikit itu dapat dipergunakan secara efektif, efisien, ekonomis, dan berkeadilan. Secara efektif maksudnya bahwa pengelolaan keuangan desa tersebut harus dapat mencapai tujuan atau sasaran yang ingin dicapai, secara efisien, maksudnya bahwa pengelolaan keuangan dimaksudkan dapat menghasilkan perbandingan terbaik antara pemasukan dengan pengeluarannya. Sedangkan secara ekonomis, maksudnya bahwa pengelolaan keuangan tersebut dapat menghasilkan perbandingan terbaik antara pemasukan dengan nilai pemasukan, adapun secara berkeadilan, maksudnya bahwa pengelolaan keuangan tersebut harus dapat memenuhi rasa keadilan dalam masyarakat (Soleh \& Rochmansjah, 2014).

Menurut Nugroho (dalam Nurhalimah, 2018) pengelolaan merupakan istilah yang dipakai dalam ilmu manajemen. Secara etimologi istilah pengelolaan berasal dari kata kelolah (to manage) dan biasanya merujuk pada proses mengurus atau menangani sesuatu untuk mencapai tujuan tertentu. Pengertian pengelolaan lebih jauh diartikan sebagai penyelenggaraan dan sebagainya. Jadi dapat disimpulkan bahwa yang dimaksud dengan pengelolaan adalah penyelenggaraan yang dilakukan dengan maksud tujuan untuk mengurus dan mengatur. Menurut Setia Mulyawan (dalam Wijaya \& Roni, 2019) secara umum manajemen keuangan merupakan hal yang berkaitan dengan kebijakan yang akan diambil dalam usaha pengendalian keuangan suatu badan hukum agar biaya yang dikeluarkan atas investasi dapat efektif.

Pengertian keuangan desa dalam UU Desa (Undang-Undang Nomor 6 Tahun 2014 tentang Desa) adalah semua hak dan kewajiban desa yang dapat dinilai dengan uang serta segala sesuatu berupa uang dan barang yang berhubungan dengan pelaksanaan hak dan kewajiban desa. Hak dan kewajiban tersebut menimbulkan pendapatan, belanja, pembiayaan yang perlu diatur dalam pengelolaan keuangan desa yang baik. Keuangan desa berasal dari pendapatan asli desa, APBD dan APBN. Penyelenggaraan urusan pemerintah daerah yang diselenggarakan oleh pemerintah desa didanai melalui APBD, sedangkan penyelenggaraan urusan pemerintah pusat yang diselenggarakan oleh pemerintah desa didanai melalui APBN.

Pemerintah desa wajib mengelola keuangan secara akuntabel, transparan, partisipatif serta dilakukan dengan tertib dan disiplin berdasarkan peraturan yang telah ditetapkan oleh 
pemrintah. Kepala desa dalam melaksanakan pengelolaan keuangan desa dibantu oleh pelaksana teknis pengelolaan keuangan desa (PTPKD), yaitu sekretaris desa dan perangkat desa lainnya. Sekretaris desa bertindak selaku koordinator pelaksanaan pengelolaan keuangan desa dan bertanggung jawab kepada kepala desa.

Definisi Keuangan Desa sebagaimana disebutkan dalam Peraturan Menteri Dalam Negeri Nomor 113 Tahun 2014 tentang Pengelolaan Keuangan Desa adalah semua hak dan kewajiban desa yang dapat dinilai dengan uang serta segala sesuatu berupa uang dan barang yang berhubungan dengan pelaksanaan hak dan kewajiban desa. Keuangan desa dikelola berdasarkan asas transparan, akuntabel, partisipasi, serta dilakukan dengan tertib dan disiplin anggaran. Pengelolaan keuangan desa dalam satu tahun anggaran antara lain tercantum dalam Anggaran Pendapatan dan Belanja Desa (APBDesa), dijelaskan bahwa sistem pengelolaan keuangan desa di mulai dari 1 Januari sampai 31 Desember di mana sistem pengelolaan keuangan desa meliputi perencanaan, pelaksanaan, penatausahaan, pelaporan dan pertanggungjawaban.

Menurut Manila I. GK. (dalam Nanang Irwan \& Aminuyati, 2020) mengatakan bahwa perencanaan merupakan suatu aktivitas menyusun hal-hal apa saja yang akan dikerjakan di masa yang akan datang, sekaligus bagaimana cara melaksanakannya. Berdasarkan penjelasan tentang konsep perencanaan, maka perencanaan dalam penelitian ini dapat diartikan sebagai suatu cakupan tindakan atau kegiatan pelaku pengelola keuangan desa dengan maksud tujuan tertentu yakni meningkatkan evektivitas dan efisiensi suatu program kegiatan, yang menyangkut langsung dengan penganggaran kegiatan tersebut. Selanjutnya Bastian (2015) menuturkan, aspek yang terkandung dalam perencanaan pembangunan khususnya perencanaan pembangunan suatu daerah kecamatan dan desa adalah pemusatan tujuan dan cara mencapai tujuan tersebut dengan memanfaatkan sumber daya yang tersedia.

Pelaksanaan atau biasa disebut dengan penggerakkan menurut Manila I. GK. (dalam Pratama, 2019) adalah aktivitas aktuasi, yang berarti setelah rencana terbentuk selanjutnya manajer harus memimpin menggerakkan para staf/bawahannya berdasarkan pada rencana yang telah terbentuk itu dengan maksud untuk mewujudkan rencana tersebut. Berkaitan dengan pengelolaan keuangan maka pelaksanaan anggaran desa yang sudah ditetapkan sebelumnya timbul transaksi atas penerimaan dan pengeluaran desa.

Menurut Shuida (2016) penatausahaan dilakukan oleh bendahara desa dan wajib melakukan pencatatan pada setiap penerimaan dan pengeluaran serta melakukan tutup buku setiap akhir bulan secara tertib. Dalam melaksanakan tugas, kewenangan, hak, dan kewajibannya dalam pengelolaan keuangan desa, kepala desa memiliki kewajiban untuk menyampaikan laporan. Laporan tersebut bersifat periodik semesteran dan tahunan, yang disampaikan ke Bupati/Walikota. Hal ini telah dijelaskan di dalam Permendagri No. 113 tahun 2014 tentang pengelolaaan keuangan desa.

Terdapat suatu konsep hukum "geen bevoegheid zonder verantwoordelijkheid atau there is no authority without responsibility", artinya tidak ada wewenang tanpa pertanggungjawaban. Setiap pemberian kewenangan kepada pejabat pemerintahan tersirat pertangungjawaban dari pejabat yang bersangkutan (Anjani, 2019).

Tjokrowinoto (dalam Pangkey, 2016) menjelaskan pengertian pembangunan secara umum adalah proses perubahan yang terus menerus untuk menuju keadaan yang lebih baik berdasarkan norma-norma tertentu. Istilah pembangunan bisa saja diartikan berbeda oleh satu orang dengan orang lainnya, daerah yang satu dengan daerah lainnya, negara satu dengan negara lainnya. Namun secara umum ada suatu kesepakatan bahwa pembangunan merupakan proses untuk melakukan perubahan. Selanjutnya pembangunan menurut Siagian adalah rangakain usaha yang secara sadar dilakukan. Artinya keadaan yang lebih baik yang didambakan, oleh suatu masyarakat, serta pertumbuhan yang diharapkan akan terus berlangsung, tidak terjadi dengan sendirinya, apalagi secara kebetulan (Annivelorita, 2015).

Sedangkan perencaanaan pembangunan desa disusun secara partisipatif oleh pemerintah desa sesuai kewenangannnya dengan melibatkan lembaga kemasyarakatan desa, karena lembaga kemasyarakatan desa merupakan mitra kerja pemerintah desa dalam aspek 
perencanaan, pelaksanaan dan pengendalian pembangunan yang bertumpu pada mayarakat (Bambang Triarsono Soemantri, 2011)

\section{Metode}

Penelitian ini merupakan penelitian yang menggunakan metode kualitatif. Sugiyono (2018) Metode penelitian kualitatif adalah metode penelitian yang berlandaskan pada filsafat postpositivisme, digunakan untuk meneliti pada kondisi obyek yang alamiah di mana peneliti adalah sebagai instrument kunci, analisis data bersifat induktif/kualitatif, dan hasil penelitian kualitatif lebih menekankan makna dari generalisasi. Fokus penelitian yaitu pengelolaan keuangan desa yang meliputi perencanaan, pelaksanaan, penatausahaan, pelaporan dan pertanggungjawaban. Penelitian ini dilakukan di pemerintahan Desa Angkasa Pura. Data penelitian diperoleh langsung dari Kepala Desa Angkasa Pura, Sekretaris Desa, Kasi Pemerintahan, Kasi Kesejahteraan dan Pelayanan, Kaur Keuangan, Kaur perencanaan dan TU, serta Ketua BPD.

Teknik pengumpulan data yang penulis gunakan di dalam penelitian ini adalah wawancara terhadap pemerintahan desa selaku pengelola keuangan desa dan masyarakat sebagai penerima mamfaat, observasi lapangan, dan dokumentasi berupa perdes dan dokumen kegiatan yang divalidasi menggunakan triangulasi. Teknik analisis data yang digunakan adalah model Miles dan Huberman. Sugiyono (2018) analisis data model Miles dan Huberman dilakukan secara interaktif dan berlangsung secara terus-menerus sampai tuntas, sehingga datanya jenuh.

\section{Hasil Penelitian dan Pembahasan}

Berdasarkan hasil penelitian yang dilakukan pada pemerintahan Desa Angkasa Pura, yaitu: Pertama, perencanan yang dilakukan oleh pemerintahan Desa Angkasa Pura dilakukan dengan melakukan musrenbang desa yang diikuti oleh pemerintah desa beserta BPD serta para tokoh masyarakat juga termasuk para pemuda karang taruna. Dalam musrenbang desa juga disampaikan tentang jumlah anggaran yang akan dikeluarkan secara garis besar yaitu mengenai pembangunan kantor kepala desa, pembangunan jalan usaha tani dalam mempermudah kegiatan ekonomi masyarakat, pemberdayaan masyarkat melalui kegiatan pelatihan. Hasil dari musyawarah yang disetujui oleh pemerintah desa dan BPD diteruskan kepada pemerintah daerah yaitu bupati dalam bentuk rancangan peraturan desa tentang APBDesa. Pada bagian kegiatan perencanaan yang dilakukan oleh permerintahan Desa Angkasa Pura terlihat sangat baik di mana melibatkan masyarakat sebagai penerima manfaat dari rencana tersebut. Akan tetapi perlu dipahami bahwa perencanaan pembangunan tidak hanya meliputi bagian fisik dan bagian non fisik tetapi bagaimana mengarahkan masyarakat menjadi partisipasi aktif bukan malah menjadi masyarakat partisipatif pasif. Dalam hal ini masyarakat sendiri memiliki peran yang sangat penting. Untuk itu perlu adanya perencanaan yang lebih ke arah pemberdayaan masyarakat terutama yang menyangkut peningkatan perekonomian masyarakat.

Kedua Pelaksanaan, pelaksanaan merupakan pengaplikasian dari rencana yang telah disetujui pada desa dalam bentuk peraturan desa. Dalam pelaksanaan kegiatan di dalam peningkatan pembangunan desa baik fisik maupun non fisik seluruhnya dilakukan oleh pemerintah desa dalam hal ini kaur dan kasi dengan dikoordinir oleh sekretaris desa, sedangkan pihak BPD melakukan pengawasan. Dari hasil wawancara dan dokumentasi dari kegiatan pelaksanaan bahwa sebagian besar dilakukan oleh masyarakat yang berdomisili di Desa Angkasa Pura, hal ini dapat terjadi karena kurang berpengalamannya masyarakat dalam bidang pembangunan gedung, pada kegiatan lain dalam hal pemberdayaan masyarkat dapat dilihat adanya keterlibatan masyarakat yang antusias dan ramai pada tiap pelaksanaan pelatihan berbasis pemberdayaan masyarakat. Dalam melakukan tahap pelaksanaan maka akan timbul transaksi atas penerimaan dan pengeluaran desa dalam hal ini dilakukan dengan sangat baik dengan menggunakan rekening kas desa. Hal lainnya perlu diperhatikan guna mendukung pembangunan desa adalah peran/partisipasi masyarkat dan BPD selaku pengawas. 
Ketiga Penatausahaan, dari hasil penelitian di mana penatausahaan terdapat permasalahan dibeban yang diberikan kepada Kaur perencanaan dan TU dan disampaikan oleh pemerintah Desa Angkasa Pura bahwa segala macam kegiatan tentang tatausaha dan pengarsipan belum sepenuhnya menggunkan Permendagri No 113 dikarenakan masih pemula dan belum berpengalaman. Sedangkan laporan pertanggungjawaban kepada Kepala Desa tidak dilakukan perbulan dikarenakan tidak adanya kegiatan yang dilaksanakan sehingga laporan pertanggungjawaban tersebut hanya bisa dilaporkan sewaktu ada kegiatan. Dengan adanya aturan dan pedoman yang jelas maka pemerintah desa terkhusus staf desa harus memahami dan dapat melakukan kegiatannya dengan sebaik-baiknya. Pemberian beban lebih kepada staf desa bisa membuat kurang efektifnya pekerjaan yang dilakukanya seperti halnya pelaporan kepada kepala desa

Keempat Pelaporan, dalam pelaporan Realisasi Pelaksanaan APBDesa di Desa Angkasa Pura dapat dilihat pada dua tahap pelaporan, laporan semester pertama dan laporan semester akhir tahun, ini telihat setelah kegiatan itu dilaksanakan selanjutnya dilakukan rapat dan evaluasi terhadap kegiatan, selanjutnya ke camat dan diberikan lagi ke Bupati ditambah lagi ada pelaporan ke Pemdes, DPPKA, dan Inspektorat. Pada bagian ini selalu terjadi keterlambatan dalam penyerahannya padahal pelaporan sangat penting mengingat pelaporan dibutuhkan untuk proses evaluasi di dalam penggunaan anggaran yang akan menentukan pencairan anggaran tahap selanjutnya.

Kelima Pertanggungjawaban, pertanggungjawaban merupakan akhir dari proses penggunaan wewenang dalam pemerintahan desa, dalam hal ini hanya dilakukan pertanggungjawaban kepada pemerintah daerah tiap akhir tahun. Untuk pertanggungjawaban terhadap masyarakat tidak dilakukan sehingga masyarakat tidak mengetahui bagaimana pengeluaran terhadap kegiatan maupun kegiatan yang dilakukan sesuai dengan perencanaan awal. Pertanggungjawaban atas segala kegiatan yang dilaksanakan merupakan hal penting akan tetapi pertanggungjawaban pemerintahan Desa Angkasa Pura hanya dilakukan kepada pemerintah daerah padahal masyarakat mempunyai hak agar dapat mengevaluasi dan mengetahui tentang pengguanaaan anggaran ataupun kegiatan yang telah dilakukan selama satu tahun.

Dalam meningkatkan pembangunan desa maka perlu adanya proses pengadministrasian yang benar, rapi, dan tertib, sehingga dapat memberikan informasi ataupun data yang akurat guna mempermudah dalam pengambilan keputusan, membuat rencana, mengontrol dan mengevaluasi. Hal yang juga penting dan memerlukan perhatian lebih adalah bagaimana pengelolaan keuangan desa dilakukan, karena setiap kegiatan perlu adanya perencanaan, pelaksanaan, penatausahaan, pelaporan dan pertanggung jawaban sesuai Permendagri No. 113 Tahun 2014. Berdasarkan hal tersebut maka pada Desa Angkasa Pura dapat dilihat, yaitu:

Pertama perencanaan, ini sesuai dengan permendagari No. 113 Tahun 2014 yang menjelaskan proses perencanaan yang dimulai dari menyususn rancangan peraturan desa hingga disepakati bersama

Kedua pelaksanaan, ini sesuai dengan Permendagri No.113 Tahun 2014 yang menjelaskan penggunaan rekening kas desa sebagai hasil dari penerimaan dan pengeluaran desa dalam rangka pelaksanaan kewenangan desa.

Ketiga penatausahaan, hal ini tidak sesuai dengan permendagri No. 113 tahun 2014 yang menjelaskan penatausahaan dan adanya pertanggungjawaban yang diberikan kepada kepala desa setiap bulan.

Keempat pelaporan, hal ini tidak sesuai dengan permendagri No. 113 Tahun 2014 yang menjelaskan penyampaian laporan realisasi pelaksanaan APBDesa pada semester pertama dan semester akhir tahun yang diberikan kepada Bupati.

Kelima pertanggungjawaban, hal ini sesuai dengan Permendagri No. 113 Tahun 2014 yang menjelaskan laporan pertanggungjawaban realisasi pelaksanaan APBDesa setiap akhir tahun anggaran kepada Bupati. 
Pemerintah desa merupakan penyelenggara urusan pemerintah di wilayah tingkat desa yang dipimpin oleh kepala desa yang bertugas menyelenggarakan urusan pemerintahan, pembangunan, dan pemberdayaan masyarakat. Kepala Desa selaku pemegang kekuasaan pengelolaan keuangan desa dan mewakili Pemerintah Desa dalam kepemilikan kekayaan milik desa, agar pembangunan fisik seperti jalan usaha tani ataupun nonfisik seperti pemberdayaan masyarakat dengan melakukan pelatihan, agar pengelolaan keuangan berjalan lancar maka pemerintah desa mengikuti sistim pengelolaan keauangan desa yang telah ditetapkan dimulai dari Perencanaa, Pelaksanaan, Penatausahaan, Pelaporan hingga pada Pertanggungjawaban sesuai dengan Permendagri No. 113 Tahun 2014.

Hasil penelitian menunjukkan adanya kekurangan dalam mengelola keuangan desa bisa menghambat kegiatan yang telah direncanakan meskipun pada bagian pelaksanaan berjalan lancar tetapi pada bagian penatausahaan bisa memberikan hambatan kepada bagian lainnya yaitu akan terjadi keterlambatan pelaporan kepada pemerintah daerah dan kepada instansi lainnya yang berwenang mengevaluasi realisasi penggunaaan anggaran APBDesa yang berdampak pada keterlambatan maupun penundaan pencairan anggaran selanjutnya. Pentingnya pengelolaan siklus keuangan desa sehingga apabila ada yang terjadi kesalahan maka akan berdampak kepada tahap selanjutnya yang akan berefek pada pembangunan desa. Dalam hasil penelitian Bawon et al. (2018) dijelaskan bahwa laporan pertanggungjawaban keuangan desa pada Desa Passi 2 Kecamatan Passi Barat belum sesuai di mana masih banyak masalah dalam pembuatan laporan Pertanggungjawaban dana desa yang sering terlambat dikarenakan hambatan-hambatan seperti kualitas sumber daya manusia, tim pendamping kecamatan, dan tim pendamping desa. Mengingat laporan pertanggungjawaban dana desa sangat penting dalam pengelolaan dana desa untuk itu agar lebih ditingkatkan lagi sumber daya manusia, pendidikan, dan pelatihan disetiap desa dalam pengoperasian komputer. Hal yang sama dapat juga dilihat pada hasil penelitian Mondale et al. (2017) pada Kampung Blang Kolak I pengelolaan keuangan desa ini tidak dikelola dengan baik. Tahapan perencanaan yang seharusnya menjadi tonggak pengelolaan keuangan desa tidak terlaksana dan berakibat fatal terhadap pengelolaan keuangan secara keseluruhan. Kegiatan pelaksanaan, penatausahaan, pelaporan dan pertanggungjawaban tidak benar-benar diterapkan sesuai dengan peraturan yang ada. Pada sisi administrasi masih belum sepenuhnya dilakukan dengan sempurna. Pertanggungjawaban administrasi keuangan kompetensi sumber daya manusia, serta lemahnya pengawasan dari pihak-pihak yang terkait, merupakan beberapa kendala yang terjadi sehingga masih memerlukan arahan dan bimbingan dari pemerintah Kabupaten Aceh Tengah.

Pembangunan yang merupakan perubahan yang terus menerus ke arah lebih baik akan berjalan lancar apabila pengelolaan keuangan desa berjalan dengan baik sesuai dengan kebutuhan masyarakat baik dibidang pendukung perekonomian maupun pemberdayaan masyarakat dan juga peraturan yang mengaturnya. Masyarakat juga membutuhkan informasi sebagai bahan evaluasi untuk melihat sejauh mana perubahan yang terjadi dan bagaimana hal itu dikelola oleh pemerintahn desa tetapi hal ini tidak dilakukan oleh pemerintahan desa.

Hasil lainnya yang dapat dilihat adalah menyangkut partisipasi masyarakat desa, ketersediaan sarana dan prasarana desa, kerjasama antar sesama perangkat desa, hingga kualitas sumber daya aparat desa yang semuanya berkaitan dan harus bisa bersinergi dengan baik dalam melakukan pembangunan desa. Hal ini sesuai dengan hasil penelitian Rahum (2015) dijelaskan bahwa faktor-faktor pendukung pengelolaan Alokasi Dana Desa (ADD) dalam pembangunan fisik Desa Krayan Makmur adalah partisipasi masyarakat sangat mendukung kegiatan ini dengan dilakukannya secara bergotong royong untuk memajukan perkembangan desa yang lebih maju. Sementara itu faktor penghambat pengelolaan Alokasi Dana Desa (ADD) dalam pembangunan fisik Desa Krayan Makmur adalah rendahnya tingkat pendidikan atau Sumber Daya Manusia (SDM) dalam pengelolaan Alokasi Dana Desa (ADD) sehingga kurang otimalnya pembangunan. Hal sama juga dapat dijelaskan oleh hasil penelitian Prastiwi (2012) dengan ikut berpartisipasi dalam pembangunan baik dalam bentuk dana, tenaga, ide maupun dalam pengambilan keputusan serta dalam perealisasiannya, akan membuat suatu desa maju dalam pembangunan. Kalaupun tingkat partisipasi desa yang satu dengan desa yang lain berbeda-beda, hal ini dikarenakan adanya kesadaran yang tinggi dari warga karena adanya kekompakan antara aparat pemerintahan desa dengan masyarakatnya 
yang hasilnya dapat secara langsung dan nyata dirasakan oleh seluruh masyarakat. Dengan adanya partisipasi masyarakat desa secara keseluruhan hasil yang telah dicapai dalam pembangunan dapat dinikmati serta dimanfaatkan masyarakat.

Harapan penulis untuk pelaksanaan keuangan dalam peningkatan pembangunan bagi pihak Perangkat Desa Angkasa Pura pada penatausahaan agar lebih memahami tentang Permendagri No 113 Tahun 2014 tentang Pengelolaan Keuangan Desa khususnya yang bersinggungan langsung dengan Pengelolaan Keuangan Desa serta memberi informasi mengenai keuangan desa melalui media informasi seperti papan pengumuman, poster maupun baliho, sehingga masyarakat mengetahui transparansi Keuangan Desa. Dan yang terakhir adalah meningkatkan partisipasi masyarakat baik dibidang pembangunan maupun gotongroyong sehingga akan meningkatakan partisipasi aktif masyarakat. Hal ini sesuai dengan hasil penelitian Husna \& Abdullah (2016) kendala yang dialami aparatur desa untuk pengelolaan keuangan desa adalah kurangnya sumber daya manusia yang handal dan faham mengenai pengelolaan keuangan desa. Sari et al. (2015) menjelaskan bahwa ketidaktahuan masyarakat tentang Alokasi Dana Desa (ADD) tentunya akan berakibat pada sulitnya mengajak warga untuk berpartisipasi di dalam pelaksanaan Alokasi Dana Desa (ADD) maupun di dalam pengawasan selama masa pelaksanaannya. Dengan kurangnya pemahaman warga akan Alokasi Dana Desa (ADD) maka warga juga akan sulit memahami tugasnya dalam turut berperan serta dalam pelaksanaan pengalokasian dana desa. Hal ini menyebabkan rendahnya pemberdayaan yang melibatkan masyarakat. Hal yang sama juga dijelaskan oleh penelitian Putra et al. (2013) di mana pelaksanaan ADD yang di dalamnya terdapat proses perencanaan, pelaksanaan dan evaluasi sesuai dengan tahapan-tahapan yang ada dalam pemberdayaan masyarakat. Keterlibatan masyarakat dalam pelaksanaan ADD mengkondisikan masyarakat berada pada tahapan pemberdayaan, di mana semua itu mengarah pada masyarakat yang mandiri pada akhirnya.

\section{Simpulan}

Desa telah mendapat tempat tersendiri dengan adanya Undang - Undang No. 6 Tahun 2014 tentang Desa dapat diartikan pentingnya desa sebagai bagian dari suatu sistim pemerintahan maupun sebagai bagian dari pembangunan dan pemberdayaan. Dengan besarnya dana yang diberikan oleh pemerintah pusat maupun daerah guna membantu peningkatan pembangunan wilayah desa agar selaras dengan wilayah perkotaan sehingga dibutuhkan adanya pengelolaan keuangan desa yang baik, efektif dan efisien dalam pengelolaan keuangan maka harus dipedomani dengan peraturan yang sudah ada serta didukung dengan SDM yang memadai.

Siklus anggaran yang terdiri dari perencanaan, pelaksanaan, penatausahaan, pelaporan, dan pertanggungjawaban harus berjalan dalam kesatuan sesuai dengan pedoman yang sudah ada. Pada hasil penelitian dan artikel penelitian yang relevan dapat dilihat: 1. Perencanaan harus dilakukan sebaik mungkin dengan masukan dan pertimbangan dari masyarakat terutama pada bagian perencanaan; 2 . Pelaksanaan meskipun kegiatan dilakukan dengan mengikuti pedoman tetapi peting adanya pelaksana yang memiliki keterampilan; 3. Pertanggungjawaban tidak hanya dilakukan kepada pemerintah daerah tetapi penting juga dilakukan kepada masyarkat; 4. Sumber Daya Manusia (SDM), hal ini sangat penting di mana segala kegiatan haruslah dilakukan dengan SDM yang terampil pada bidangnya.

Dengan adanya pengelolaan keuangan desa yang baik akan memberikan dampak pada rencana pembangunan desa baik fisik maupun non fisik yang sudah ditetapkan. Besar harapan masyarakat terhadap pemerintahan desa harus selalu menjadi motivasi untuk selalu bekerja dengan sebaik-baiknya serta penting adanya peran ikut serta masyarakat dalam kegiatan pembangunan desa.

\section{Daftar Kepustakaan}

Anjani, A. K. (2019). Pertanggungjawaban Pengelolaan Dana Desa. Jurist-Diction, 2(3), 747. https://doi.org/10.20473/jd.v2i3.14288 
Annivelorita. (2015). Implementasi Alokasi Dana Desa (ADD) Dalam Meningkatkan Pembangunan Desa Liang Butan Krayan Kabupaten Nunukan. EJournal Administrasi Negara, 3(5), 1712-1726.

Bambang Triarsono Soemantri. (2011). Pedoman Penyelenggaraan Pemerintah Desa. Fokusmedia.

Bastian, I. (2015). Akuntansi untuk Kecamatan \& Desa. Jakarta : Erlangga.

Bawon, R. W., Karamoy, H., \& Warongan, J. D. L. (2018). Analisis Prosedur Pelaksanaan Pengelolaan Dana Desa Pada Desa Passi 2 Kecamatan Passi Barat. Jurnal Riset Akuntansi Going Concern, 13(4), 210-213.

Husna, S., \& Abdullah, S. (2016). Kesiapan Aparatur Desa Dalam Pelaksanaan Pengelolaan Keuangan Desa Secara Akuntabilitas Sesuai Undang-Undang Nomor 6 Tahun 2014 Tentang Desa ( Studi pada Beberapa Desa di Kabupaten Pidie). Jurnal Ilmiah Mahasiswa Ekonomi Akuntansi (JIMEKA), 1(1), 282-293. http://www.jim.unsyiah.ac.id/EKA/article/view/774

Mondale, T. F., Aliamin, \& Fahlevi, H. (2017). Peran Perangkat Desa Dalam Akuntanbilitas Pengelolaan Keuangan Desa ( Studi Pada Desa Karangsari Kecamatan Sukodono ). Jurnal Ilmiah Ilmu Akuntasi, Keuangan Dan Pajak (ASSETS), 1, 29-46. https://doi.org/https://doi.org/10.30741/assets.v1i2.28

Nanang Irwan, Aminuyati, F. Y. K. (2020). Analisis Pengelolaan Dana Desa Dalam Upaya Meningkatkan Perekonomian Masyarakat Desa Kuala Karang. Jurnal Pendidikan Dan Pembelajaran Khatulistiwa, 9.

Nurhalimah, A. (2018). Partisipasi Kaum Perempuan Dalam Perencanaan Pengelolaan Dana Desa. Jurnal Ilmu Administrasi Negara (JUAN), 6(2). http://ojs.umrah.ac.id/index.php/juan/article/view/795

Pangkey, D. K. A. (2016). Peran Kepala Desa dalam Pelaksanaan Pembangunan di Desa Tateli Satu Kecamatan Mandolang Kabupaten Minahasa. Politico: Jurnal Ilmu Politik, 03.

Prastiwi, M. (2012). Partisipasi Masyarakat Terhadap Peningkatan Pembangunan Desa. Buletin Ekonomi, 8(1), 1-8.

Pratama, A. A. (2019). Perencanaan dan Pelaksanaan Alokasi Dana Desa (ADD) Di Desa Pengalihan Kecamatan Enok Kabupaten Indragiri Hilir Tahun 2017-1018. Jurnal Online Mahasiswa Fakultas Ilmu Sosial Dan Ilmu Politik (JOM FISIP), 6. https://www.oecd.org/dac/accountable-effective-institutions/Governance Notebook 2.6 Smoke.pdf

Putra, C. K., Ratih Nur Pratiwi, \& Suwondo. (2013). Pengelolaan Alokasi Dana Dsa Dalam Pemberdayaan Masyarakat Desa (Studi pada Desa Wonorejo Kecamatan Singosari Kabupaten Malang). Jurnal Administrasi Publik (JAP), 1(6), 1203-1212.

Rahum, A. (2015). Pengelolaan Alokasi Dana Desa (Add) Dalam Pembangunan Fisik Desa Krayanmakmur Kecamatan Long Ikis Kabupaten Paser. EJournal Ilmu Pemerintahan, 3(4), 1-14.

Sari, R. N., Ribawanto, H., \& Said, M. (2015). Pengelolaan Alokasi Dana Desa dalam Perspektif Pemberdayaan Masyarakat. Jurnal Administrasi Publik (JAP), 3(11), 18801885.

Shuida, I. N. (2016). Buku Bantu Pengelolaan Pembangunan Desa. Deputi Koordinasi Pemberdayaan.

Soleh, C., \& Rochmansjah, H. (2014). Pengelolaan Keuangan Desa. Fokusmedia.

Sugiyono. (2018). Metode Penelitian Kuantitatif Kualitatif dan R\&D. Bandung: Alfabeta.

Wijaya, E., \& Roni, M. F. (2019). Praktik Pengelolaan Keuangan Desa Dan Faktor-Faktor 
Yang Memengaruhinya. Jurnal Ilmiah Kebijakan Hukum, 13(2), 165-184.

https://doi.org/http://dx.doi.org/10.30641/kebijakan.2019.V13.165-184

Undang - Undang No. 6, Tahun 2014, Tentang Desa

Peraturan Menteri Dalam Negeri No: 113 Tahun 2014, Tentang Pedoman Pengelolaan Keuangan Desa 